\title{
LANDASAN PEMIKIRAN TENTANG PEMBEBANAN JAMINAN DALAM KONTRAK PEMBIAYAAN MUDHARABAH PERSPEKTIF UU NO. 21 TAHUN 2008 TENTANG PERBANKAN SYARIAH
}

\author{
Mhd. Yadi Harahap ${ }^{1}$ \\ Email: Yadhimuhammad79@gmail.com \\ Fakultas Hukum dan Syariah Universitas Islam Negeri Sumatera \\ Utara
}

\begin{abstract}
Abstrak
The practice of sharia banking in Indonesia, the provision of mudharabah financing is generally followed by the provision of guarantees by business actors, since mudharabah financing contracts which are not followed by collateral are difficult to obtain mudharabah financing. Sharia banking interpreting collateral is an additional collateral for businesses managed by business actors in accordance with article 1 verse 26 of Law no. 21 of 2008 concerning Sharia Banking. For Sharia Banks Mudharabah financing guarantee is the second source of payment of capital given while the main source is the result of mudharib's business. When the business actor fails to fulfill its obligations to the sharia bank, the guarantee can be used as an effort to anticipate the failure to pay the financing provided. The problems that form the basis of this research is what is the basis of the idea of imposition of collateral in mudharabah financing contract perspective of Law no. 21 of 2008. To analyze the above research question the author uses normative juridical research as a method so that found a comprehensive, systematic, critical, constructive and argumentative answers.
\end{abstract}

Keywords: jaminan, kontrak, pembiayaan, mudharabah, UU No. 21 tahun 2008 tentang perbankan syariah.

\section{Pendahuluan}

Secara teknis pembiayaan mudharabah (trust financing) adalah kontrak kemitraan (partnership) dengan prinsip bagi hasil antara shahibul maal sebagai pemilik modal dan mudharib sebagai pengelola untuk melakukan kegiatan usaha dengan kemampuan dan keahlian yang dimiliki mudharib. ${ }^{2}$ Kontrak mudharabah, mudharib bisa perorangan, badan hukum, dan atau perusahaan untuk memperoleh modal. ${ }^{3}$ Keuntungan dari pembiayaan mudharabah dibagi berdasrkan nisbah yang telah disepakati sebelumnya dengan pembagian menggunakan metode bagi untung (profit sharing) atau metode

\footnotetext{
${ }^{1}$ Dosen Pada Fakultas Syariah dan Hukum Universitas Islam Negeri Sumatera Utara dan Universitas Kristen Indonesia. Saat ini tengah menyelesaiakan Program Doktor Ilmu Hukum pada Fakultas Hukum Universitas Indonesia.

${ }^{2}$ Muhammad Imran Ashraf Usmani, Meezan Banks Guide to Islamic Banking, (Pakistan: Darul Ishaat Urdu Bazar, 2002), hlm. 105.

${ }^{3}$ Veithzal Rivai dkk. Principle Of Islamic Finance (dasa-dasar keuangan Islam). Saatnya Hijrah ke Sistem Keuangan Islam yang Telah Teruji Kemampuannya. Cetakan Pertama, (Yogyakarta: Fakultas Ekonomi dan Bisnis, Universitas Gajah Mada, 2012), hlm.184.
}

bagi pendapatan (revenue sharing). ${ }^{4}$ Apabila terjadi risiko kerugian atas usaha yang dibiayai karena proses normal, maka seluruh kerugian ditanggung sepenuhnya oleh shahibul maal sebagai pemilik modal. ${ }^{5}$ Sementara mudharib sebagai pengelola kehilangan usaha untuk mendapatkan keuntungan, waktu, pikiran dan tenaga yang telah dicurahkan selama mengelola usaha tersebut. ${ }^{6}$

\footnotetext{
${ }^{4}$ Metode bagi laba (profit sharing) dihitung dari total pendapatan setelah dikurangi seluruh biaya operasional. Sedangkan metode bagi pendapatan (revenue sharing) dihitung dari total pendapatan musyarakah yang diterima bank sebagai shahibul maal. Pembagian bagi hasil dilakukan berdasarkan laporan realisasi hasil usaha dan usaha nasabah. Pengembalian pokok pembiayaan dilakukan diakhir periode akad atau diakukan secara angsuran. Muhammad, Audit dan Pengawasan Syariah Pada Bank Syariah: Catatan Pengalaman Disertai Dengan Contoh Laporan Audit dan Pengawasan, Cetakan Pertama, (Yogyakarta: UII Press, 2003), hlm. 60. Lihat Juga, Cecep Maskanul Hakim, Belajar Mudah Ekonomi Islam: Catatan Kritis Tterhadap Dinamika Perkembangan Perbankan Syariah di Indonesia, Cetakan Pertama, (Tangerang: Shuhuf Media Insani, 2011), hlm. 69.

${ }^{5}$ Afzalur Rahman, Ekonomic Doctrines Of Islam. Penerjemah oleh Soeroyo, Nastangin. Doktrin Ekonomi Islam Jilid IV, Cetakan Pertama, (Yogyakarta: Dana Bhakti Wakaf, 1996), hlm. 380. Lihat Juga Suhrawardi K. Lubis, Hukum Ekonomi Islam, Cetakan Pertama, (Jakarta: Sinar Grafika, 2000), hlm. 52.

6 Abdurrahman Al-Jaziri, al-Fiqh 'Ala Madzahib al-Arba'ah, (Beirut: Dar al-Qalam, t.t.), hlm 34-35. Lihat juga Veithzal Rivai dkk. op.cit., hlm.184.
} 
Jika kerugian tersebut disebabkan dari akibat kelalaian, danmenyalahiperjanjiandalamkontrakdan penyimpangan yang dilakukan oleh mudharibseperti penyelewengan, kecurangan dan penyalahgunaan modal yang diberikan, maka pengelola harus bertanggung jawab atas kerugian tersebut. ${ }^{7}$ Ciri utama pembiayaan mudharabah adalah bahwa keuntungan dan kerugian ditanggung bersama oleh pemilik modal maupun pelaku usaha. Tidak ada bagian keuntungan tanpa ambil bagian dalam risiko (al-ghunmu bilghurm $)^{8}$, atau untuk setiap keuntungan ekonomi riil harus ada biaya riil (al-kharaju bil-daman). Hal ini menunjukkan bahwa keuntungan tidak boleh dituntut tanpa ada kemungkinan menanggung risiko. ${ }^{9}$

Prinsip pembiayaan mudharabah berdasarkan prinsip trust (kepercayaan), yaitu kepercayaan dari shahibul maal kepada mudharib. Selain prinsip kepercayaan, prinsip lainadalahterciptanyahubungan kemitraan, semangat kerja sama, tolong menolong ( $t a$ 'awun), dan persaudaraan (ukhuwah) dalam bentuk usahayangberkeadilandengandimensifilosofisbahwa investasi mudharabah merupakan penyatuan antara modal dengan usaha. ${ }^{10}$ Kepercayaan merupakan unsur penentu dalam kontrak pembiayaan mudharabah, karena itu shahibul maal dapat mengakhiri kontrak mudharabah secara sepihak apabila shahibul maal tidak memiliki keprcayaan terhadap mudharib. ${ }^{11}$ Pemilik modal maupun pelaku usaha mempunyai insentif yang sama untuk menciptakan kegiatan usaha yang menguntungkan, dengan memperhatikan prinsip kehati-hatian, dan berupaya memperkecil kemungkinan risiko kegagalan usaha. ${ }^{12}$ Seperti yang dipraktikkan Rasululloh dengan Khadijah dalam bidang perniagaan, di mana Rasululloh sebagai mudharib dan Khadijah sebagai shahibul maal yang kemudian menjadi istrinya. ${ }^{13}$ Adapun jangka waktu

\footnotetext{
Fathurrahman Djamil, Penerapan Hukum Perjanjian Dalam Transaksi di Lembaga Keuangan Syariah, Cetakan Pertama, (Jakarta: Sinar Grafika, 2012), hlm.173. Lihat Juga, Muhammad, Paradigma, Metodologi dan Aplikasi Ekonomi Syariah, Cetakan Pertama, (Yogyakarta: Graha Ilmu, 2008), hlm. 156.

${ }^{8}$ Fuad al-Omar, Muhammad Abd. Haq, Islamic Banking: Theory, Practice and Challenges, ( Karachi: Oxford University Press, 1996), hlm. 87.

${ }^{9}$ Muhammad Fahmi Khan, Economics Series: Essays in Islamic Economic, ( United Kongdom: The Islamic Foundation, 1995), hlm. 172.

${ }^{10}$ Elias G. Kazarian, Islamic Versus Traditional Banking: Financial Innovation in Egypt, (Boulder: Westview Press, 1993), hlm. 61.

${ }^{11}$ Sutan Remy Sjahdeini, Perbankan Syariah: Produk-Produk dan Aspek-Aspek Hukumnya, Cetakan Pertama, ( Jakarta: Kencana Prenadamedia Group, 2014), hlm. 295.

${ }^{12}$ Amir Machmud. Rukmana, Bank Syariah: Teori, Kebijakan, dan Studi Empiris di Indonesia, Cetakan Pertama, (Jakarta: Erlangga, 2010), hlm. 56.

13 Hendi Suhendi, Fiqh Muamalah: Membahas Ekonomi Islam Kedudukan Harta, Hak Milik, Jual Beli, Bunga Bank dan Riba, Musyarakah, Ijarah, Mudayanah, Koperasi, Asuransi, etika Bisnis dan lain-lian, Cetakan Pertama, (Jakarta: Raja Grafindo Persada, 2008), hlm. 139. Lihat juga Wiroso, Penghimpun Dana dan Distribusi Hasil Usaha Bank Syariah, Cetakan Pertama, (Jakarta: Grasindo, 2011), hlm. 34.
}

pembiayaan dan pengembalian dana sertapembagian keuntungan ditentukan berdasarkan kesepakatan antara shahibul maal dan mudharib berdasarkan rasio yang dituangkan dalam bentuk kontrak. ${ }^{14}$

Undang-undang No. 21 Tahun 2008 tentang Bank Syariah, memberikan penjelasan bahwa kontrak pembiayaan mudharabah ${ }^{15}$ adalah akad kerja sama suatu usaha antara pihak pertama sebagai shahibul maal atau bank syariah yang menyediakan dana seluruh modal dan pihak kedua sebagai mudharib yang bertindak sebagai pengelola dana dengan membagi keuntungan usaha sesuai dengan kesepakatan yang dituangkan dalam kontrak, sedangkan kerugian ditanggung sepenuhnya oleh bank syariah kecuali jika pihak kedua melakukan kesalahan yang disengaja, lalai atau menyalahi perjanjian. ${ }^{16}$ Konsep mudharabah bank syariah memiliki hak untuk melakukan pengawasan dan pembinaan usaha mudharib walaupun tidak ikut serta dalam pengelolaan usaha mudharib. ${ }^{17}$ Antara lain bank

\footnotetext{
${ }^{14}$ Tamrin Abdullah, Francis Tantri, Bank dan Lembaga Keuangan, Cetakan Pertama, (Jakarta: Raja Grafindo Persada, 2012), hlm. 219.

15 UU Perbankan No. 7 Tahun 1992 sebagaimana telah diubah dengan Undang-undang No. 10 Tahun 1998, menggunakan dua istilah yang berbeda dalam rangka menyalurkan dana kepada debitur, tetapi mengandung makna yang sama yaitu kredit dan pembiayaan. Penggunaan istilah tersebut tergantung kepada kegiatan usaha yang dijalakan oleh bank itu sendiri, apakah bank dalam menjalankan kegiatan usahanya secara konvensioanl atau berdasarkan prinsip syariah. Bank yang menjalankan kegiatan usahanya secara konvensional menggunakan istilah kredit, sedaangkan bank yang menjalankan usahanya berdasarkan prinsip syariah menggunakan istilah pembiayaan. Istilah kredit disebutkan pada pasal 1 angka (11), dan istilah pembiayaan berdasarkan prinsip syariah disebutkan dalam pasal 1 angka (12) UndangUndang perbankan. Kredit adalah penyediaan uang atau tagihan yang dapat dipersamakan dengan itu berdasarkan persetujuan atau kesepakatan pinjam meminjam antara bank dan pihak lain yang mewajibkan pihak peminjam untuk melunasi utangnya setelah jangka waktu tertentu dengan pemberian bunga. Sedangkan pembiayaan berdasarkan prinsip syariah adalah penyediaan uang atau tagihan yang dipersamakan dengan itu, berdasarkan persetujuan atau kesepakatan antara bank dan pihak lain yang mewajibkan pihak yang dibiayai utnuk mengembalikan uang atau tagihan tersebut setelah jangka waktu tertentu dengan imbalan bagi hasil. Selanjutnya, pengertian pembiayaan diperjelas lagi dalam ketentuan Pasal 1 angka 3 Peraturan Bank Indonesia No. 9/19/PBI/2007 menyatakan sebagai berikut: Pembiayaan adalah penyediaan dana atau tagihan/piutang yang dapat dipersmakan dengan itu dalam transaksi investasi yang didasarkan antara lain atas akad mudharabah dan atau musyarakah. Pengertian yang sama juga dirumuskan dalam ketentuan Pasal 1 angka 25 UU No. 21 Tahun 2008 tentang Perbankan Syariah yaitu: Pembiayaan adalah penyediaan dana atau tagihan yang dipersamakan dengan itu berupa transaksi bagi hasil dalam bentuk akad mudharabah dan musyarakah. Racmadi Usman, Aspek-Aspek Hukum Perbankan di Indonesai, Cetakan Pertama, (Jakarta: Gramedia Pustaka Utama, 2001), hlm. 237.

${ }^{16}$ Pasal 19 ayat (1) huruf c dan penjelasannya Undang-Undang Perbankan Syariah Nomor 21 Tahun 2008.

17 Akad pembiayaan mudharabah dibedakan menajadi dua yaitu mudharabah muthlaqah dan mudharabah muqayyadah. Wahbah al-Zuhaili menegaskan bahwa yang dimaksud dengan mudharabah muthlaqah adalah penyerahan modal dari shahibul maal kepada mudharib untuk melakukan usaha tanpa ditentukan jenis usahanya, tempatnya, waktunya, sifat usahanya, dan pihak yang melakukan usha tersebut. Sedangkan yang dimaksud dengan mudharabah muqayyadah adalah kontrak berupa penyerahan modal dari shahibul maal kepada mudharib untuk melakukan usaha, di mana jenis usahanya telah ditentukan, tempatnya, waktunya, sifatnya, dan pihak yang melakukan usaha tersebut. Wahbah al-Zuhaili, Fiqhul Islam wa Adillatuhu, (Beirut: Dar al-fikr tt.), hlm. 3924. Lihat Juga, Burhanuddin, Hukum bisnis syariah, Cetakan Pertama, (Yogyakarta: UII Press, 2011), hlm. 126.
} 
dapat melakukan review dan meminta bukti-bukti dari laporan hasil usaha mudharib berdasarkan bukti pendukung yang dapat dipertanggungjawabkan. ${ }^{18}$

Liquat ali Khan Niazi dalam bukunya yang berjudul "Islamic Law of Contract" menyatakan kontrak pembiayaan mudharabah disebut kontrak kerjasama karena antara pemilik modal dan pelaku usaha merupakan pasangan (partner), secara langsung saling membutuhkan satu dengan yang lain. Pemilik modal membutuhkan pelaku usaha untuk menjalankan modal dari dana yang dimilikinya, sementara pelaku usaha yang mempunyai keahlian, kesempatan dan kemampuan untuk melakukan usaha membutuhkan modal bagi usaha yang akan dilakukannya. ${ }^{19}$ Kepentingan saling membutuhkan secara langsung inilah yang diakomodasi dalam kontrak pembiayaan mudharabah. Bahwa kontrak mudharabah merupakan sebagai bentuk kerjasama berangkat dari falsafah hukum ekonomi Islam yang menganggap bahwa modal dan kerja bukan sebagai faktor yang terpisah, tetapi sebagai kesatuan dasar yang saling menguntungkan. "Islam does not regard capital and interpreneurship as distinct factors with a separate basis foreward, rather as copartners with a uniform basis on return". ${ }^{20}$

Berdasarkan falsafah tersebut, maka modal mempunyai kedudukan yang sama dan sederajat dengan profesionalitas usaha. Profesionalitas usaha tidak dapat di subordinasikan dengan modal, sebaliknya modal juga tidak dapat di subordinasikan dengan profesionalitas usaha. Kedudukan yang sama dan sederajat ini harus diaktualisasikan dalam ketentuan-ketentuan yang mengatur hak dan kewajiban antara pemilik modal dan profesionalitas usaha. Pembiayaan mudharabah berbeda dengan sistem pinjam meminjam atau utang piutang uang yang menempatkan pemilik modal dan pelaku usaha dalam kedudukan yang tidak sederajat, tetapi dalam kedudukan sub ordinatif. Hubungan keduanya adalah dalam kategori hubungan kreditur dan debitur. ${ }^{21}$ Konstruksi normatif yang ditimbulkan dari hubungan yang demikian adalah bukan sebagai bentuk hubungan hukum kerjasama tetapi hubungan hukum antara kreditur dan debitur. Hak dan kewajiban yang dapat dikonstruksikan oleh hukum terhadap hubungan kreditur dan debitur akan berbeda dengan hak dan kewajiban dalam hubungan kerjasama bidang

\footnotetext{
${ }^{18}$ Wangsawidjaja Z. Pembiayaan Bank Syariah, Cetakan Pertama, (Jakarta: Gramedia Pustaka Utama, 2012), hlm. 193.

${ }^{19}$ Liaquat Ali Khan Niazi, Islamic Law Of Contract. (Lahore: Research Cell Dyal Sing Tust Library,1990), hlm. 232.

${ }^{20}$ Muhammad Nejatullah Siddiqi, Partnership And Profit Sharing in Islamic Law, (Leicester: The Islamic Foundation, 1985, hlm. 5.

${ }^{21}$ Burhanuddin Harahap, Kedudukan, Fungsi dan Problematika Jaminan dalam Perjanjian Pembiayaan Mudharabah pada Perbankan syariah, Jurnal Yustisia, Edisi 69, 2006, hlm. 46.
}

mudharabah. Maka ketentuan-ketentuan normatif yang berlaku dalam hubungan pinjam meminjam atau utang piutang tidak dapat diterapkan dalam kontrak pembiayaan mudharabah.

\section{Permasalahan}

1. Bagaimana pemikiran yang melatarbelakangi dipersyaratkanjaminandalamkontrakpembiayaan mudharabah pada perbankan syariah?

2. Bagaimana menjadi argumentasi hukum tentang pembebanan jaminan dalam kontrak pembiayan mudharabah perspektif Undang-undang Nomor 21 Tahun 2008 Tentang Perbankan Syariah?

\section{Tujuan Penulisan}

1. Untuk mengetahui dasar pemikiran pembebanan jaminan dalam kontrak pembiayan mudharabah perspektif UU No. 21 Tahun 2008 Tentang Perbankan Syariah.

2. Untuk menganalsis argumentasi hukum tentang pembebanan jaminan dalam kontrak pembiayana mudharabah perspektif UU No. 21 tahun 2008 Tentang Perbankan Syariah.

\section{Pembebanan Jaminan dalam Kontrak Pembiayaan Mudharabah Perspekti UU}

Pembiayaan dengan sistem bagi hasil dapat dilakukan melalui akad mudharabah dengan karakteristik terdiri dari pihak pertama sebagai pemilik modal disebut dengan shahibul maal, dan pihak kedua sebagai pengelola usaha yang diistilahkan dengan mudharib. Pada akad mudharabah di perbankan syariah dekenal dengan sebutan two-tier atau dua tahap mudharabah, hal ini karena lembaga perbankan syariah merupakan lembaga perantara atau intermediaries sebagai dasar penghimpunan dana masyarakat untuk kemudian disalurkan kembali kepada masyarakat dalam berbagai bentuk pembiayaan dan penyertaan modal. ${ }^{22}$ Prinsipnya bank syariah merupakan bank dengan landasan utamanya adalah prinsip bagi hasil dalam segala bentuk operasionalnya, baik dalam penghimpun maupun penyaluran dana. Pengumpulan dana yang diperoleh dari pihak ketiga melalui wadi'ah yad dhmanah, tabungan dan deposito mudharabah dan lain-lain. Kemudian disalurkan melalui bentuk pembiayaan dengan prinsip mudharabah, murabahan, isthis'na ataupun salam. ${ }^{23}$

\footnotetext{
${ }^{22}$ Manzoor Ali, Islamic Banking and Finance in Theory and Practice, (Jeddah: IRTI-IDB, 1412 H/1992), hlm. 345

${ }^{23}$ Ascarya, Diana Yumanita, Bank Syariah: Gambaran Umum, Seri Kebanksentralan, Cetakan Pertama, (Jakarta: Bank Indonesia dan Pusat Pendidikan dan Studi Kebanksentralan, 2005), hlm. 38.
} 
Pernyataan tersebut menegaskan bahwa pada perbankansyariahdikenalduasisiperananbanksyariah, satu sisi sebagai penghimpun dana dari masyarakat dalam hal ini bank berperan sebagai pengelola usaha melalui akad mudharabah dengan pemilik tabungan dan deposito mudharabah sebagai shahibul maal. Pada sisi lain bank syariah berperan sebagai penyalur dana kepada masyarakat dalam hal ini bank seabagai shahibul maal melalui akad mudharabah dengan nasabah sebagai mudharib. ${ }^{24}$ Adanya kendala yang dihadapi perbankan syariah dalam hal mpembiayaan mudharabah merupakan kendala teknis, baik internal (bank) maupun eksternal (nasabah), serta tingginya risiko menjadi pertimbangan utama mengapa bank syariah kurang tertarik untuk memberikan pembiayaan mudharabah, tanpa dibarengi dengan pembenanan jaminan. Untuk saat ini masih sangat sulit mencari pengusaha yang jujur dan amanah, sehingga bank syariah perlu memperhatikan secara mendalam terkait dengan prilaku moral haazard mudharib, karena kunci keberhasilan pembiayaan mudharabah sangat tergantung kepada prilaku dan karakter dari mudharib. ${ }^{25}$

Selain yang disebutkan di atas, perbankan syariah perlu memahami secara mendalam terkait dengan pemberian dan fasilitas pembiayaan mudharabah yaitu: Pertama, kepercayaan atau keyakinan bank syariah bahwa modal yang diberikan melalui pembiayaan mudharabah akan benar-benar diterima kembali sesuai dengan kontrak yang disepakati terlebih kontrak pembiayaan mudharabah adalah akad yad al-amanah yaitu akad kepercayaan. Kedua, kesepakatan. selain unsur kepercayaan dalam kontrak pembiayaan mudharabah, unsur kesepakatan antara bank syariah dengan mudharib harus dituangkan dalam bentuk perjanjian secara tertulis di mana masing-masing pihak menandatangani hak dan kewajibanya. Ketiga, Jangka waktu. Pada prinsipnya salah satu syarat yang harus dipenuhi dalam kontrak pembiayaan mudharabah adalah adanya jangka waktu tertentu. ${ }^{26}$ Keempat, degree of risk yaitu jangka waktu yang telah ditetapkan dalam kontrak pembiayaan mudharabah akan menimbulkan risiko jika tidak dikembalikannnya modal yang diberikan oleh bank syariah. Semakian panjang jangka waktu yang diberikan, maka kemungkin risiko pembiayaan mudharabah akan semakin besar. ${ }^{27}$

\footnotetext{
${ }^{24}$ Nayyer Manzoor, Islamic Economic a Welfare Approach, (New Delhi: Adam Publishers and Distributor, 2006), hlm. 49.

${ }^{25}$ Bank Indonesia, Biro Perbankan Syariah Bank Indonesia, $\mathrm{Ka}$ jian Awal Cetak Biru Pengembangan Perbankan Syariah di Indonesia, (Jakarta: Bank Indonesia), hlm. 11.

${ }^{26}$ Kasmir, Bank dan Lembaga keuangan Lainnya, Edisi Revisi (Jakarta: Raja Grafindo Persada, 2008), hlm. 99.

${ }^{27}$ Thomas Suyatno, H.A. Chalik, Made Sukada, C. Tinon Yuniati, Dasar-Dasar Perkreditan, Edisi Keempat, (Jakarta: Gramedia Pustaka Utaman Kerja Sama Sekolah Tinggi Ilmu Ekonomi Perbanas, 2007), hlm. 14.
}

Pembiayaan mudharabah dalam konteks fiqih dan yang dikenal selama ini berlaku secara langsung antara shahibul maal dan mudharib yang sudah saling kenal mengenal antara keduanya seperti telah diparaktikkan oleh oleh Nabi Muhammad saw. para sahabat dan umat Islam sesudahnya. Konsep ini dikenal dengan investasi langsung (direct financing) antara shahibul maal sebagai surplus unit dengan mudharib sebagai deficit unit. ${ }^{28}$ Sementara untuk saat ini, konsep pembiayaan mudharabah secara langsung antara shahibul maal dan mudharib tidak efesien lagi dan kecil kemungkinannya tidak dapat diterapkan oleh bank syariah karena beberapa hal:

1. Sistem kerja pada bank adalah investasi berkelompok, di mana antara individu tidak saling kenal mengenal, sehingga tertutup kemungkinan terjadi hubungan langsung secara personal.

2. Banyaknya investasi yang dibutuhkan oleh pelaku usaha dalam jumlah yang besar, sehingga diperlukan modal dari berbagai shshibul maal sebagai penyandang dana untuk satu proyek tertentu.

3. Memngingat banyaknya mudharib yang mengajukan kontrak pembiayaan mudharabah, sangat sulit untuk mengenal karakter dan tanggung jawab setiap mudharib.

4. Modal yang diberikan kepada mudharib merupakan modal pihak ketiga, maka jaminan merupakan sebagai salah satu antisipasi untuk menghindari moral hazard. ${ }^{29}$

Untuk mengatasi hal di atas khususnya masalah pertama dan kedua, maka perlu dilakukan inovasi baru dalam kontrak pembiayaan mudharabah, di mana awalnya hanya melibatkan antara dua pihak secara langsung, menjadi mudharabah yang melibatkan pihak ketiga atau yang dikenal dengan istilah mudharabah dua tingkat atau pembiayaan mudharabah pararel, yaitu melalui perantara bank syariah sebagai lembaga intermediary sehingga terjadi evolusi dari konsep direct financing menjadi indirect financing, artinya modal yang diberikan oleh bank syariah kepada pelaku usaha tidaklah merupakan milik penuh bank syariah melainkan milik berbagai nasabah yang menitipkan dananya dengan berbagai akad. Pola hubungan segi tiga seperti ini, pemilik modal, bank syariah, dan pelaku usaha akan mempunyai kontrak langsung dengan pemilik modal sekaligus dengan pelaku usaha. Posisi seperti ini bank syariah akan bertindak sebagai perantara antara

\footnotetext{
${ }^{28}$ Surplus unit adalah pihak-pihak yang memiliki kelebihan dana yakni pemilik modal, sedangkan deficit unit adalah pihak-pihak yang membutuhkan dana untuk usaha yakni pelaku usaha.

${ }^{29}$ Muhammad Sadi Is, Konsep Hukum Perbankan Syariah, Pola Relasi Sebagai Institusi Intermediasi dan Agen Investasi, Cetakan Pertama (Malang: Setara Press, 2015), hlm. 120.
} 
pemilik modal dengan pelaku usaha. Bank Syariah sebagai instrumen untuk memobilisasi tabungan dari nasabah kemudian memberikan modalnya kepada para pengusaha dengan konsep pembiayaan mudharabah. ${ }^{30}$

Penerapan kontrak pembiayaan mudharabah pada bank syariah diimplementasikan menjadi tiga pihak, yakni (1) Para nasabah penyimpan dana adalah sebagai shshibul maal; (2) Bank syariah sebagai suatu intermediary dan pengusaha sebagai mudharabah yang membutuhkan dana; dan (3) Bank bertindak seabagai mudharib dalam hal bank syariah menerima dana dari nasabah dan sebagai shahibul mall dalam hal bank menyediakan dana bagi para mudharib. Pada sisi penghimpun dana kontrak pembiayaan mudharabah diterapkan pada (1) Tabungan berjangka yaitu tabungan yang dimaksudkan untuk tujuan khusus, seperti tabungan haji, tabungan qurban, dan sebagainya; (2) Deposito biasa, deposito spesial (special investmen) di mana dana yang dititipkan nasabah khusus untuk bisnis tertentu, misalnya mudharabah saja atau ijarah saja. ${ }^{31}$ Sedangkan pada posisi pembiayaan, mudharabah diterapkan dalam bentuk: (1) Pembiayaan modal kerja seperti modal kerja perdagangan dan jasa; (2) Investasi khusus disebut juga mudharabah muqayaadah, dimana sumber dana khusus dengan penyaluran yang khusus dengan syarat-syarat tertentu yang telah ditetapkan oleh shahibul maal. ${ }^{32}$

Penerapan pembiayaan mudharabah pada bank syariah diaplikasikan dalam bentuk mudharbah dua tingkat, dikarenakan fungsi bank syariah sebagai lembaga intermediary atau perantara antara pemilik modal yang menitipkan dananya kemudian bank syariah menyalurkannya dalam berbagai produk dan dalam bentuk pembiayaan. Perbedaan dan karakteristik hukum pembiayaan mudharabah dengan mudharabah dua tingkat terletak pada ketentuan:

1. Pihak-pihak yang terkait dalam kontrak pembiayaan mudharabah adalah shahibul maal (pemilik modal) dan mudharib (pengelola usaha), sedangkan dalam mudharabah dua tingkat terdiri dari shahibul maal, mudharib dan bank syariah sebagai intermediary.

2. Kontrak pembiayaan mudharabah tidak melibatkan bank syariah sebagai intermediary, tetapi langsung kedua pihak antara shahibul maal dan mudharib. Sedangkan mudharabah dua tingkat bank syariah sebagai pihak yang

\footnotetext{
${ }^{30}$ Abdel Fattah M. farah, An In troduction to Islamic Banking and Finance, First Edition, (International Islamic University: AlKHaleej Printing Press, 2009), hlm. $93 .$.

${ }^{31}$ Akhmad Mujahidin, Hukum Perbankan Syariah, Cetakan Pertama, (Jakarta: Raja Grafindo Persada, 2016), hlm. 74.

${ }^{32}$ Ibid.
}

menyediakan sejumlah modal baik dari modal dari shahibul maal maupun dari bank syariah sebagai intermediary dengan mudharib.

3. Pembagian bagi hasil dilakukan hanya antara shahibul maal dan mudharib, sedangkan dalam mudharabah dua tingkat mudharib akan berbagi hasil dengan bank syariah, kemudian bank syariah akan berbagi hasil dengan pihak shahibul maal. Posisi seperti ini bank syariah bertindak sebagai agen investasi. ${ }^{33}$

Mudharib tidak diperbolehkan menyerahkan aset mudharabah kepada orang lain tanpa mendapatkan kesepakatan dari pemilik modal baik hanya sebagai titipan atau diberdayakan oleh pihak ketiga (mudharib kedua). Jika aset yang diterima mudharib kedua hanya sebagai titipan, maka mudharib pertama tidak berkewajiban menanggung risiko yang ada, karena hanya diposisikan sebagai wadiah. ${ }^{34}$ Namun jika mudharib pertama menyerahkan aset mudharabah kepada mudharib kedua dengan maksud investasi, maka mudharib pertama memilki tanggung jawab penuh terhadap shahibul maal. Mudharib pertama bertanggung jawab penuh atas aset mudharabah, baik hanya sebagai titipan atau investasi, seperti halnya ketika menitipkan titipan kepada orang lain. ${ }^{35}$ Jika penyerahan aset tersebut dimaksudkan untuk investasi dan digunakan mudharib kedua untuk menjalankan bisnis, maka mudharib pertama bertanggung jawab penuh atas aset mudharabah, karena terkait dengan hak kepemilikan orang lain. apabila terdapat keuntungan dalam mudharabah pararel akan dibagi sesuai dengan kesepakatan mudharabah pertama. Keuntungan mudharib pertama, akan dibagi dengan mudharib kedua sesuai kesapakatan dalam akad mudharabah kedua. ${ }^{36}$

Keuntungan yang diperoleh dari kontrak pembiayaan mudharabah adalah: (a) Bank syariah akan menikmati peningkatan bagi hasil pada saat keuntungan usaha nasabah meningkat; (b) Bank syariah tidak berkewajiban membayar bagi hasil kepada nasabah pendanaan secara tetap, tetapi disesuaikan dengan pendapatan hasil usaha bank syariah sehingga bank syariah tidak akan pernah mengalami negative spread; (c) Pengembalian pokok pembiayaan disesuaikan dengan cash flow (arus kas) usaha nasabah, sehingga tidak memberatkan nasabah; (d) Bank syariah lebih selektif dan hati-hati dalam

\footnotetext{
${ }^{33}$ Muhammad Saldi Is, op.cit., hlm. 153.

${ }^{34}$ Abdul Ghofur Anshori, Pengantar Ekonomi Syariah: Konsep Dasar, Paradigma, Pengembangan Ekonomi Syariah, Cetakan Pertama, (Jakarta: Raja Grafindo Persada, 2017), hlm. 139.

${ }^{35}$ Dimyauddin Djuwaini, Ikwan Abidin Basri, Zainul Arifin, dkk, Pengantar Fiqh Muamalah: Landasan Manajemen dan Transaksi Bisnis, Cetakan Pertama, (Bogor: Lembaga Penelitian dan Pemberdayaan Masyarakat LPPM-Tazkia, 2007), hlm. 138.

${ }^{36}$ Wahbah al-Zuhayli, al-fiq al-Islam wa al-Adillatuh, Juz 4, op.cit, hlm. 858-861.
} 
mencari usaha yang benar-benar halal, aman, dan menguntungkan karena keuntungan yang konkret dan benar terjadi itulah yang akan dibagikan; (e) Prinsip kontrak pembiayaan mudharabah berbeda dengan prinsip bunga tetap, konesp pembiayaan mudharabah, pemilik modal akan menagih penerimaan pembiayaan sesuai dengan pendapatan hasil usaha, sedangkan prisnip bunga akan menagih penerima pembiayaan sejumlah bunga tetap berapapun keuntungan yang dihasilkan oleh pelaku usaha sekalipun merugi dan terjadi krisis ekonomi. ${ }^{37}$

Untuk saat ini, penerapan kontrak pembiayaan mudharabah telah mengalami perubahan di mana pada awalnya hubungan antara shahibul maal dan mudharib secara langsung telah menjadi kontrak segi tiga yaitu antara bank syariah, pemilik modal, dan pelaku usaha, bahkan seringkali bank syariah bertindak sebagai pemilik modal ketika berhadapan dengan pelaku usaha, dan pada saat yang sama bertindak sebagai mudharib ketika berhadapan dengan penabung pemilik modal atau investor. Ketika bank syariah berkedudukan sebagai pihak ketiga akan memiliki kesempatan untuk menentukan syaratsyarat dan ketentuan dalam kontrak pembiayaan mudharabah, hal ini dilakukan untuk menghindari kemungkinan moral hazard dari pelaku usaha. ${ }^{38}$

Selain itu pembiayaan mudharabah dalam praktiknya telah berubah dari kontrak kepercayaan (yad al-amanah) dalam fikih, menjadi kontrak pertanggungjawaban (yad adh-dhamana) yang mengharuskan jaminan, pengawasan, pengujian dan penentuan syarat-syarat untuk mengamankan modal dari berbagai risiko yang ditimbulkan. Konsep pembiayaan mudharabah pada awalnya merupakan kontrak bagi hasil dengan kerugian hanya ditanggung oleh pemilik modal, dalam praktiknya bagaimana agar kerugian tersebut tidak hanya dibebankan kepada pemilik modal. Untuk menjaga kepercayaan terhadap banksyariah, makabanksyariahmenerapkanberbagai persyaratan yang dibebankan kepada mudharib. Perubahan konsep dan berbagai modifikasi tersebut dapat disesuaikan terhadap realitas perbankan syariah saat ini, namun secara akademisi harus diletakkan pada persoalan yang sebenarnya. ${ }^{39}$

Adapun mekanisme kontrak pembiayaan mudharabah pada bank syariah menurut Peraturan Bank Indonesia Nomor: 7/46/PBI/2005Tentang akad Penghimpun dan Penyaluran Dana Bagi Bank yang Melaksanakan Kegiatan Usaha Berdasarkan Prinsip Syariah adalah:

\footnotetext{
${ }^{37}$ Ridjaluddin FN, Pemikiran Islam Tentang Kerjasama Bagi Hasil dalam Nuansa-Nuansa Ekonomi Islam, Cetakan Pertama, (Sejahtera Percetakan dan Perdagangan Umum, 2007), hlm. 129.

${ }^{38}$ Zainuddin Ali, Hukum Ekonomi Syariah, Cetakan Pertama, (Jakarta: Sinar Grafika, 2008), hlm. 105.

${ }^{39}$ Ibid.
}

a. Bank bertindak sebagai shahibul maal yang menyediakan dana secara penuh, dan nasabah bertindak sebagai mudharib yang mengelola dana dalam kegiatan usaha.

b. Jangka waktu pembiayaan, pengambilan dana dan pembagian keuntungan ditentukan berdasarkan kesepakatan bank dan nasabah.

c. Bank tidak ikut serta dalam pengelolaan usaha nasabah tetapi memiliki hak dalam pengawasan dan pembianaan usaha nasabah.

d. Pembiayaan diberikan dalam bentuk tunai dan atau barang, dalam hal pembiayaan diberikan dalam bentuk barang maka barang yang diserahkan harus dinilai berdasarkan harga perolehan atau harga pasar wajar.

e. Pembagian keuntungan dari pengelolaan dana dinyatakan dalam bentuk nisbah yang disepakati dan dituangkan dalam kontrak pembiayaan mudharabah. Nisbah bagi hasil yang disepakati tidak dapat diubah sepanjang jangka waktu investasi, kecuali atas dasar kesepakatan para pihak dan tidak berlaku surut.

f. Nisbah bagi hasil dapat diterapkan secara berjenjang (tiering) yang besarnya berbeda-beda berdasakan kesepakatan pada awal kontrak.

g. Bank sebagai penyedia dana menanggung seluruh risiko kerugian usaha yang dibiayai kecuali nasabah melakukan kecurangan, lalai, atau menyalahi perjanjian yang mengakibatkan kerugian usaha.

h. Bagihasildalamkontrakpembiayaanmudharabah dapat dilakukan dengan menggunakan dua metode yaitu bagi laba (profit sharing) atau bagi pendapatan (revenue sharing), dan pembagian keuntungan bagi hasil berdasarkan laporan realisasi hasil usaha nasabah.

i. Pengembalian pokok pembiayaan dialakukan pada kahir periode akad pembiayaan dengan jangka waktu sampai dengan satu tahun atau dilakukan secara angsuran berdasarkan aliran kas masuk (cash in flow) usaha nasabah.

j. Jika salah satu pihak tidak melakukan kewajiban ataumelakukanpelanggaranterhadapkesepakatan dengan unsur kesengajaan maka bank atau pihak yang dirugikan berhak mendapat ganti rugi ( $t a$ 'widh) atas biaya riil yang telah dikeluarkan. $\mathrm{k}$. Pada prinsipnya, dalam pembiayaan mudharabah tidak ada jaminan, namun dalam rangka prinsip kehati-hatian, bank syariah dapat meminta jaminan kepada nasabah pada saat penyaluran pembiayaan. Jaminan yang diterima oleh bank hanya dapat dicairkan apabila nasabah terbukti melakukan pelanggaran terhadap kesepakatan akad pembiayaan mudharabah. i. Keriteria pengusaha, prosedur pembiayaan, dan mekanisme 
pembagian keuntungan diatur oleh bank selaku

mudharib berdasarkan perinsp kehati-hatian bank dengan memperhatikan prinsip syariah. ${ }^{40}$

Seorang mudharib dapat berupa perorangan, badan hukum, dan mudharib merupakan al-amin atas modal yang diberikan, karena itu mudharib adalah seorang wakil yang diamanahkan sehingga pada saat proyek usaha telah selesai mudharib berkewajiban mengembalikan modal tersebut kepada pemilik modal berikut porsi keuntungan yang telah disetujui dalam kontrak. Bank syariah akan membayar bagi hasil kepda nasabah setiap akhir bulan, sesuai dengan nisbah yang telah disepakati dalam kontrak pada saat pembukaan rekening tabungan mudharabah. Bagi hasil yang diterima nasabah akan selalu berubah pada akhir bulan, hal ini disebabkan karena adanya fluktuasi pendapatan bank syariah dan fluktuasi dana tabungan nasabah. Keistimewaan lain dari kontrak pembiayaan mudharabah adalah peran ganda mudharib, yakni sebagai wakil (agen) sekaligus mitra. Mudharib adalah wakil dari shahibul maal dalam setiap transaksi yang dilakukan dalam kontrak pembiayaan mudharabah, mudharib kemudian menjadi mitra dari shahibul maal ketika ada keuntungan karena mudharabah adalah kemitraan dan keuntungan. ${ }^{41}$

\section{Argumentasi Hukum Tentang Pembebanan Jaminan dalam Kontrak Pembiayaan Mudharabah Menurut Undang-Undang}

Perbankan Syariah merupakan institusi yang keberadaannya sangat memerlukan adanya kepercayaan dan keyakinan dari masyarakat akan modal yang dititipkan kepadanya melalui berbagai produk dan pembiayaan perbankan syariah. Hal ini karena ruh dari perbankan syariah adalah kepercayaan, apabila kepercayaan dari masyarakat hilang maka bisa dipastikan operasional perbankan termasuk perbankan syariah akan berhenti, karena prinsipnya dana yang dimiliki oleh perbankan syariah sebagian besar merupakan dana yang dimiliki oleh berbagai nasabah. Untuk menjaga kepercayaan masyarakat bank hendaknya mampu melaksanakan dengan optimal prinsip tata kelola perbankan yang sehat dan

\footnotetext{
${ }^{40}$ Khotibul Umam, Legislasi Fikih Ekonomi dan Penerapannya dalam Produk Perbankan Syariah, Edisi Revisi, Cetakan Pertama, (Yogyakarta: Fakultas Ekonomi dan Bisnis Universisat Gadjah Mada, 20110, hlm.90. diambil dari Peraturan Bank Indonesia Nomor: 7/46/PBI/2005 Tentang akad Penghimpun dan Penyaluran Dana Bagi Bank yang Melaksanakan Kegiatan Usaha Berdasarkan Prinsip Syariah.

${ }^{41}$ Bank Indonesia, Mencari Solusi Pembiayaan Bagi Hasil Perbankan Syariah: Proceeding Seminar Nasional, Cetakan Pertama, (Jakarta: Lembaga Pengembangan Perbankan Indonesia Bank Indonesia, 2004), hlm. 13. Lihat Juga Imran Ahsan Khan Nyazee, Islamic Law and Jurisprudence-1: Islamic Law of Business Organization Partnership, op.cit. hlm. 250.
}

baik (good corporate governance) ${ }^{42}$ Tata kelola yang dimaksud adalah menerapkan tata kelola yang baik yang mencakup prinsip transparansi, akuntabilitas, pertanggungjawaban, profesional, kejujuran, keadilan, dan kewajaran dalam menjalankan kegiatan usahanya. ${ }^{43}$

Prinsipyangsangatpentingdalamrangkamenjaga dan mempertahankan kepercayaan masyarakat terhadap bank syariah yaitu prinsip kehati-hatian (prudential principle). Prinsip ini dituangkan dalam pasal 35 ayat (1) Undang-undang Nomor 21 Tahun 2008 Tentang Perbankan Syariah, ${ }^{44}$ hal ini perlu dalam rangka menjamin terlaksananya pengambilan keputusan dalam pengelolaan bank syariah sesuai dengan prinsip kehati-hatian dengan menerapkan antara lain melakukan sistem pengawasan interen. ${ }^{45}$ Begitu juga pada pasal 8 ayat (1) dan ayat (2) Undang-undang Perbankan Nomor 10 Tahun 1998.46 Berkaitan dengan pasal 35 undang-undang perbankan syariah tentang prinsip kehati-hatian, mempertegas kewajiban bank syariah dan UUS untuk menerapkan prinsip kehati-hatian dalam melakukan kegiatan usaha bank syariah. Prinsip kehati-hatian yang dimaksud merupakan pedoman pengelolaan bank syariah dan UUS dalam rangka mewujudkan perbankan syariah yang sehat, kuat, dan efesien sesuai dengan ketentuan peraturan perundang-undangan. Selain pasal 35 ayat (1), pasal 2 Undang-Undang Nomor 21 Tahun 2008 Tentang Perbankan Syariah menetapkan bahwa bank dalam melakukan usahanya wajib menerapkan prinsip syariah dan prinsip kehati-hatian berdasarkan rambu-rambu yang telah ditetapkan. ${ }^{47}$

\footnotetext{
${ }^{42}$ Good Corporate Governance adalah suatau tata kelola bank yang menerapkan prinsip-prinsip keterbukaan (transparency), akuntabilitas (accountability), pertanggungjawaban (responsibility), independensi (independency), dan kewajaran (fairness). Lihat Pasal 1 angka 6 Peraturan Bank Indonesia No. 8/4PBI/2006 Tentang Pelaksanaan Good Corporate Governance Bagi Bank Umum. Berkaitan dengan tata kelola, pasal 34 ayat (1) Undangundang Perbankan Syariah menentukan bahwa perbankan syariah wajib menerapkan tata kelola yang baik yang mencakup prinsip tranparansi, akuntabilitas, pertanggungjawaban, profesional, dan kewajaran dalam menjalankan kegiatan usahanya.

${ }^{43}$ Bank BNI Syariah, Peluang dan Tantangan Bank Syariah di Indonesia, Cetakan Pertama, (Jakarta: Al-Kautsar Prima, 2006), hlm. 71.

${ }^{44}$ Pasal 35 ayat (1) Undang-Undang Nomor 21 Tahun 2008 menyebutkan bahwa Bank Syariah dan UUS dalam melakukan kegiatan usahanya wajib menerapkan prinsip kehati-hatian.

${ }^{45}$ Pasal 35 ayat (1) dan penjelasannya Pada Undang-undang Nomor. 21 Tahun 2008 Tentang Perbankan Syariah.

${ }^{46}$ Pasal 8 ayat (1) dan ayat (2) Undang-undang No. 10 Tahun 2008 Tentang Perbankan. Bahwa dalam memberikan kredit atau pembiayaan berdaasarkan prinsip syariah, bank umum wajib mempunyai keyakinan berdasarkan analisis yang mendalam atas iktikad dan kemampuan serta kesanggupan nasabah debitur untuk melunasi utangnya atau mengembalikan pembiayaan dimaksud sesuai dengan yang diperjanjikan. Ayat (2) Bank Umum wajib memiliki dan menerapkan pedoman perkreditan dan pembiayaan berdasarkan prinsip syariah, sesuai dengan ketentuan yang ditetapkan oleh Bank Indonesia.

${ }^{47}$ Pasal 35 ayat (1) Undang-Undang Nomor 21 Tahun 2008 Tentang Perbankan Syariah menyebutkan bahwa bank syariah dan UUS dalam melakukan kegiatan usahanya wajib menerapkan prinsip kehati-hatian.
} 
Lebih lanjut dalam rangka melaksanakan prinsip kehati-hatian dalam menyalurkan pembiayaan mudharabah dan melakukan kegiatan usaha lainnya, bank syariah dan UUS wajib menempuh cara-cara yang tidak merugikan bank syariah dan/atau UUS dan kepentinagn nasabah yang mempercayakan dananya. Selanjutnya pasal 37 UU perbankan syariah menegaskan bahwa Bank Indonesia menetapkan ketentuan mengenai batas maksimum penyaluran dana berdasarkan prinsip syariah, pemberian jaminan, penempatan investasi surat berharga yang berbasis syariah, atau hal lain yang serupa, dan dapat dilakukan oleh bank syariah dan UUS kepada nasabah penerima fasilitas yang terkait. Termasuk kepada perusahaan dalam kelompok yang sama dengan bank syariah dan UUS yang bersangkutan. Adapun batas maksimum yang dimaksud tidak boleh melebihi 30 persen dari modal bank syariah sesuai dengan ketentuan yang ditetapkan oleh bank Indonesia. ${ }^{48}$

Penyaluran dana pembiayaan berdasarkan prinsip syariah oleh bank syariah dan UUS mengandung risiko kegagalan atau kemacetan dalam pelunasannya sehingga dapat berpengaruh terhadap kesehatanbank syariah dan UUS. Mengingat bahwa penyaluran dana yang dimaksud bersumber dari dana masyarakat yang disimpan pada bank syariah dan UUS, risiko yang dihadapai bank syariah dan UUS dapat berpengaruh pula kepada keamanan dana masyarakat tersebut. Untuk memelihara kesehatan dan mengingat daya tahannya, bank diwajibkan menyebar risiko dengan mengatur penyaluran pemberian pembiayaan berdasarkan prinsip syariah. Pemberian jaminan ataupun fasilitas lain sedemikian rupa sehingga tidak berpusat pada nasabah debitur atau kelompok nasabah debitur tertentu. ${ }^{49}$

Pasal 25 ayat (1) UU No. 23 Tahun 1999, menjelaskan dalam rangka melaksanakan tugas mengatur bank, Bank Indonesia berwenang menetapkan ketentuan perbankan yang memuat prinsip kehatihatian. Pelaksanaan kewenangan sebagaimana dimaksud pada ayat 1 ditetapkan dengan Peraturan Bank Indonesia. ${ }^{50}$ Hal yang sama juga diintroduksi pasal 23 Undang-undang No. 21 Tahun 2008 Tentang Perbankan Syariah dan Pasal 8 Undang-undang No. 10 Tahun 1998 Tentang Perbankan menentukan: (1) Dalam memberikan kredit atau pembiayaan berdasarkan prinsip syariah, bank umum wajib mempunyai keyakinan berdasarkan analisis mendalam atas iktikad dan kemampuan serta kesanggupan nasabah debitur untuk melunasi utangnya atau mengembalikan pembiayaan dimaksud sesuai dengan yang diperjanjikan; dan (2) Bank umum wajib memiliki dan menerapkan pedoman pembiayaan

\footnotetext{
${ }^{48}$ Pasal 37 ayat $(1,2$,dan 3$)$ dan penjelasannya Undang-Undang Nomor 21 Tahun 2008 Tentang Perbankan Syariah

${ }^{49}$ Pasal 37 ayat (1,) dan penjelasannnya Undang-Undang Nomor 21 Tahun 2008 Tentang Perbankan Syariah.

${ }^{50}$ Pasal 25 Ayat 91, dan 2) Undang-undang Republik Indonesia Nomor 23 Tahun 1999 Tentang Bank Indonesia.
}

berdasarkan prinsip syariah, sesuai dengan ketentuan yang ditetapkan oleh Bank Indonesia. ${ }^{51}$

Penjelasan pasal 23 UU No. 21 tahun 2008 dan pasal 8 UU No. 10 Tahun 1998 menyebutkan pembiayaan berdasarkan prinsip syariah yang diberikan oleh bank mengandung risiko, sehingga dalam pelaksanaannya harus memperhatikan asasasas pembiayaan berdasarkan prinsip syariah yang sehat. Untuk mengurangi risiko tersebut, jaminan atas kemampuan dan kesanggupan nasabah debitur untuk melunasi kewajibannya sesuai dengan yang diperjanjikan merupakan faktor penting yang harus diperhatikan bank. ${ }^{52}$ Untuk memperoleh keyakinan tersebut sebelum memberikan pembiayaan mudharabah bank harus melakukan penilaian yang seksama terhadap watak, ${ }^{53}$ kemampuan, ${ }^{54}$ modal, ${ }^{55}$ agunan $^{56}$ dan prospek usaha dari nasabah mudharib ${ }^{57}$. Penjelasan ini menegaskan bahwa pembiayan yang diberikan oleh bank syariah dalam kontrak pembiayaan mudharabah tidaklah

\footnotetext{
${ }^{51}$ Sekalipun berbeda redaksi antara pasal 23 yang dikemukakan dalam Undang-undang Nnomor 21 Tashun 2008 Tentang perbankan Syariah dengan Pasal 8 Undang-Unadng Nomor 10 Tahun 1998 Tentang Perbankan, akan tetapi prinsip dan esensialnya tetap sama, yaitu adanya sebuah kewajiban bahwa bank harus meyakini kesanggupan nasabah, debitur ataupun mudharib dalam hal melunasi kewajibannya. Lebih lanjut dapat dilihat pada pasal pasal 23 Undangt-undang No. 21 Tahun 2008 Tentang Perbankan Syariah dan Pasal 8 Undang-undang No. 10 Tahun 1998 Tentang Perbankan.

52 Terkait dengan penjelasan di atas dapat dilihat dalam pasal 23 Undang-undang Nomor. 21 Tahun 2008 dan pasal 8 Undangundang Nomor. 10 Tahun 1998 Tentang perbankan.

${ }^{53}$ Penilaian watak calon Nasabah Penerima Fasilitas terutama didasarkan kepada hubungan yang telah terjalin antara Bank Syariah dan/atau UUS dan Nasabah atau calon Nasabah yang bersangkutan atau informasi yang diperoleh dari pihak lain yang dapat dipercaya sehingga Bank Syariah dan/atau UUS dapat menyimpulkan bahwa calon Nasabah Penerima Fasilitas yang bersangkutan jujur, beriktikad baik, dan tidak menyulitkan Bank Syariah dan/ atau UUS di kemudian hari. Penjelasan Pasal 23 Undang-undang Nomor 21 Tahun 2008 Tentang Perbankan Syariah.

${ }^{54}$ Penilaian kemampuan calon Nasabah Penerima Fasilitas terutama Bank harus meneliti tentang keahlian Nasabah Penerima Fasilitas dalam bidang usahanya dan/atau kemampuan manajemen calon Nasabah sehingga Bank Syariah dan/atau UUS merasa yakin bahwa usaha yang akan dibiayai dikelola oleh orang yang tepat. Penjelasan Pasal 23 Undang-undang Nomor 21 Tahun 2008 Tentang Perbankan Syariah.

${ }^{55}$ Penilaian terhadap modal yang dimiliki calon Nasabah Penerima Fasilitas, terutama Bank Syariah dan/atau UUS harus melakukan analisis terhadap posisi keuangan secara keseluruhan, baik untuk masa yang telah lalu maupun perkiraan untuk masa yang akan datang sehingga dapat diketahui kemampuan permodalan calon Nasabah Penerima Fasilitas dalam menunjang pembiayaan proyek atau usaha calon Nasabah yang bersangkutan. Penjelasan Pasal 23 Undang-undang Nomor 21 Tahun 2008 Tentang Perbankan Syariah.

${ }^{56}$ Dalam melakukan penilaian terhadap Agunan, Bank Syariah dan/ atau UUS harus menilai barang, proyek atau hak tagih yang dibiayai dengan fasilitas Pembiayaan yang bersangkutan dan barang lain, surat berharga atau garansi risiko yang ditambahkan sebagai Agunan tambahan, apakah sudah cukup memadai sehingga apabila Nasabah Penerima Fasilitas kelak tidak dapat melunasi kewajibannya, Agunan tersebut dapat digunakan untuk menanggung pembayaran kembali Pembiayaan dari Bank Syariah dan/ atau UUS yang bersangkutan. Penjelasan Pasal 23 Undang-undang Nomor 21 Tahun 2008 Tentang Perbankan Syariah.

${ }^{57}$ Penilaian terhadap proyek usaha calon Nasabah Penerima Fasilitas, Bank Syariah terutama harus melakukan analisis mengenai keadaan pasar, baik di dalam maupun di luar negeri, baik untuk masa yang telah lalu maupun yang akan datang sehingga dapat diketahui prospek pemasaran dari hasil proyek atau usaha calon Nasabah yang akan dibiayai dengan fasilitas Pembiayaan. Penjelasan Pasal 23 Undang-undang Nomor 21 Tahun 2008 Tentang Perbankan Syariah.
} 
sepenuhnya milik bank, melainkan milik nasabah lain yang mempercayakan dananya kepada bank sehingga dalam memberikan fasilitas pembiayaan mudharabah kepada mudharib. Bank syariah mensyaratkan pembebanan jaminan sebagai bentuk keyakinanbank syariah dan iktikat mudharib terhadap modal yang telah diberikan.

Argumentasi lain bahwa sumber pelunasan modal yang diberikan dalam bentuk pembiayaan mudharabah adalah usaha mudharib yang menghasilakn pendapatan yang diistilahkan dengan first way out dan second way out berupa jaminan. Second way out merupakan pembebanan jaminan tertentu atas suatu benda apabila tejadi pembiayaan bermasalah. Bank syariah sebagai shahibul maal berhak menjual barang yang menjadi jaminan dan mengambil hasil penjualan atas barang tersebut sebagai sumber pelunasan pembiayaan mudharabah. Penjaualan objek yang menjadi jaminan dapat dilakukan oleh shahibul maal apabila terbukti bahwa mudharib melakukan kecurangan, menyalahi perjanjian, dan melakukan moral hazard. ${ }^{58}$

Selain jaminan dalam bentuk benda bergerak dan benda tidak bergerak, jaminan dalam kontrak pembiayaan mudharabah dapat juga dilakukan dengan jaminan pihak ketika yaitu perjanjian penanggungan (borgtocht) hal ini juga dilakukan untuk mengamankan posisi bank syariah ketika mudharib melakukan moral hazard. Pembebanan jaminan yang diikuti jaminan pihak ketiga biasanya dilakukan dalam hal adanya kekhawatiran bank syariah jika kerugian bank syariah tidak mencukupi atau rendahnya harga barang jaminan yang berhasil dilelang dan tidak cukup untuk menutupi modal yang telah diberikan kepada mudharib. ${ }^{59}$

Makna penting yang dapat disimpulkan dari prinsip kehati-hatian di atas adalah, bahwa perbankan syariah dalam hal menyalurkan pembiayaan perbankan syariah termasuk kontrak pembiayaan mudharabah harus dikelola dengan baik yang mencakup prinsip transparansi, akuntabilitas, pertanggungjawaban, independensi, dan kewajaran dalam menjalankan kegiatan usahanya berdasarkan kepada undang-undang perbankan syariah. Pembiayaan yang dilakukan harus berdasarkan pertimbangan ekonomis dan profesionalitas, bukan berdasarkan pertimbangan lain di luar kepentingan ekonomi. Berkaitan dengan pengelolaan perbankan syariah berdasarkan prinsip transparansi, akuntabilitas, pertanggungjawaban, profesional, dan kewajaran dalam menjalankan kegiatan usahanya mempunyai risiko

\footnotetext{
${ }^{58}$ Fathurrahman Djamil, Penyelesaian Pembiayaan Bermasalah di Bank Syariah, Cetakan Kedua, (Jakarta: Sinar Grafika, 2014), hlm. 44.

${ }^{59}$ Abdul Somad, Hukum Islam Penormaan Prinsip Syariah dalam Hukum Indonesia, op.cit, hlm. 195.
}

yang berat, karena pelakunya bertanggung jawab dunia akhirat. ${ }^{60}$

Transparansi yang dimaksud adalah keterbukaan dalam mengemukakan informasi yang material dan relevan dalam melaksanakan proses pengambilan keputusan. Akuntabilitas adalah kejelasan fungsi, pelaksanaan dan pertanggungjawaban keuangan sehingga pengelolaan perusahaan berjalan secara efektif. Pertanggungjawaban adalah kesesuaian pengelolaan Entitas Utama dan Lembaga Jasa Keuangan dengan peraturan perundang-undangan dan prinsip prinsip pengelolaan yang sehat. Independensi adalah pengelolaan konglomerasi keuangan secara profesional tanpa pengaruh atau tekanan dari pihak manapun. Kewajaran adalah keadilan dan kesetaraan dalam memenuhi hak hak pemangku kepentingan yang timbul berdasarkan perjanjian dan peraturan perundang-undangan. ${ }^{61}$

Tujuan penerapan prinsip kehati-hatian untuk menjaga agar bank syariah selalu dalam keadaan likuid dan solvent, artinya bank syariah selalu dalam keadaan sehat, sehingga kepercayaan masyarakat terhadap perbankan tetap tinggi dan masyarakat tidak akan ragu menyimpan dananya pada bank syariah. Prinsip kehati-hatian yang diterapkan oleh perbankan syariah bukan hanya karena dihubungkan dengan kewajiban bank agar tidak merugikan nasabah yang mempercayakan dananya kepada bank syariah, melainkan menyangkut kepentingan masyarakat umum dan perbankan pada khusunya agar bank menjalankan usahanya secara baik dan benar dengan mematuhi secara konsisten mematuhi ketentuan dan norma hukum yang berlaku dalam perbankan. ${ }^{62}$

Dapat disimpulkan bahwa prinsip kehati-hatian dan prinsip risiko merupakan prinsip yang sangat penting dalam kontrak pembiayaan mudharabah, karena prinsip kehati-hatian dan prinsip risiko dalam penyaluran kontrak pembiayaan mudharabah merupakan keniscayaan agar bank dalam mengelola dana masyarakat dapat berhasil dengan optimal dan mampu memberikan manfaat bagi nasabah. Mengingat hubungan antara pemilik modal dengan mudharib dalam kontrak pembiayaan mudarabah merupakan hubungan kontraktual yang dilandasai dengan prinsip kehati-hatian dan prinsip risiko. ${ }^{63}$

\footnotetext{
${ }^{60}$ Zubairi Hasan, Undang-Undang Perbankan Syariah: Titik Temu Hukum Islam dan Hukum Nasional, Cetakan Pertama, (Jakartaa: Raja Grafindo Persada, 2009), hlm. 116.

${ }^{61}$ Lihat penjelasan pasal 1 angka 6 Peraturan Bank Indonesia No. 8/4PBI/2006 Tentang Pelaksanaan Good Corporate Governance Bagi Bank Umum.

${ }^{62}$ Sutan Remy Sjahdeini, Kebebasan Berkontrak dan Perlindungan yang Seimabang bagi Para Pihak dalam Perjanjian Kredit Bank di Indonesia, Cetakan Pertama, (Jakarta: Institut Bankir Indonesia, 1993), hlm. 175. Dapat Juga Dilihat dalam, Djawahir Hejazziey, Hukum Perbankan Syariah, op.cit. hlm. 112.

${ }^{63}$ Roni Sautama Hotma Bako, Hubungan Bank dan Nasabah Terhadap Produk Tabungan dan Deposito: Suatu Tinjaun Hukum Terhadap Perlindungan Deposan di Indonesia Dewasa Ini, Cetakan Pertama, (Bandung: Citra Aditya Bakti, 1995), hlm. 51.
} 
Penerapan prinsip kehatia-hatian dan prinsip risikotentuakandapatmenaikkantingkatkepercayaan masyarakat terhadap bank syariah, jika dilakukan dengan konsisten sesuai peraturan perundangundangan yang berlaku. Penjelasan Undang-undang perbankan syariah mengamanatkan bahwa prinsip kehati-hatian dalam hal pembiayaan perbankan syariah khusunya pembiayaan mudharabah harus dipegang secara konsisten untuk menghindari hilangnnya kepercayaan masyarakat yang menitipkan dananya. ${ }^{64}$

Menerapkan perinsip kahtai-hatian dan prinsip risiko dalam pengelolaan bank, perbankan syariah diwajibkan untuk tidak melakukan cara-cara yang dapat merugikan perbankan syariah serta nasabah yangtelahmempercayakandananyadalammelakukan kegiatan usahanya. Hal ini senada dengan ketentuan pasal 36 undang-undang perbankan syariah. ${ }^{65}$ Pada dasarnya ketentuan dalam pasal 36 undangundang pebankan syariah sejalan dengan ketentuan pasal 29 ayat (3) Undang-undang Nomor 7 Tahun 1992 sebagaimana telah diubah dengan UndangUndang Nomor 10 Tahun 1998, menjelaskan bahwa perbankan syariah diwajibkan untuk menjamin kepentingan nasabah dan bank dari segala perbuatan yang dapat menimbulkan kerugian ketika bank tidak menerapkan rambu-rambu kehati-hatian, risiko dan kesehatan bank syariah dalam melakukan kegiatan penyaluran pembiayaan. Pengaturan tentang prinsip kehati-hatian dan prinsip risiko pada bank syariah dilakukan karena nasabah tidak berada dalam posisi untuk menilai dan mengetahui keamanan dan kesehatan dari bank syariah itu sendiri. ${ }^{66}$

Selain itu kontrak pembiayaan mudharabah sesungguhnya tidak pernah lepas dari risiko yang sewaktu-waktudapatmenyebabkankerugianbagibank syariah. Risiko yang dimaksud bisa saja disebabkan character risk dari mudharib, dalam kondisi seperti ini tanggung jawab kerugian dibebankan kepada mudharib. Untuk menghindari hal yang disebutkan di atas maka pembebanan jaminan dapat dibenarkan. Tujuan pembebanan jaminan dimaksudkan bukan untuk mengamankan nilai investasi jika terjadi kerugian, tetapi lebih kepada mengantisipasi karakter mudharib $\cdot{ }^{67}$ Selain itu praktik operasional perbankan

\footnotetext{
${ }^{64}$ Abdul Ghafur Ansori, op.cit, hlm. 93.

${ }^{65}$ Ketentuan pasal 36 Undang-undang Nomor 21 Tahun 2008 Tentang Perbankan Syariah secara tegas menyatakan bahwa dalam menyalurkan pembiayaan dan melakukan kegiatan usaha lainnya, bank syariah dan UUS wajib menempuh cara-cara yang tidak mrugikan bank syariah dan/atau UUS dan kepentingan nasabah yang mempercayakan dananya.

${ }^{66}$ Hasanuddin Rahman, Daeng Naja, Hukum Kredit dan Bank Garansi: The Bankers Hand Book, Cetakan Pertama, (Bandung: Citra Adytia Bakti, 2005), hlm. 294.

${ }^{67}$ Trisadini Prasastinah Usanti, Konsep Utang dalam Akad Pembiayaan Mudharabah pada Bank Syariah, Jurnal Adil, Volume 4, Nomor, 2, 2014, hlm. 316.
}

syariah selalu terjadi trade off antara service and risk, sehingga akan mengalami risiko default. ${ }^{68}$ Perbankan syariahperlumemperhatikanadanyapenerapanunsurunsur $3 \mathrm{~K}$ dalam kontrak pembiayaan mudharabah yaitu, kepercayaan, keterbukaan dan keberhatian. Kepercayaan diperlukan karena perbankan syariah merupakan bisnis yang menjalankan fungsinya sebagai financial intermediary yang mempertemukan surplus unit of fund dengan deficit unit of fund. Sehingga dengan adanya kepercayaan, diperlukan keterbukaan sebagai bentuk pertangung jawaban dalam kontrak pembiayaan mudharabah. ${ }^{69}$

\section{Kesimpulan}

Salah satu yang melatarbelakangi pemikiran tentang pembebanan jaminan dalam kontrak pembiayaan mudharabah adalah bahwa kontrak pembiayaan mudharabah yang dipraktikkan selama ini dikenal dengan investasi langsung (direct financing) antara pemilik modal sebagai surplus unit dengan pelaku usaha sebagai deficit unit. Sementara untuk saat ini, konsep pembiayaan mudharabah secara langsung tidak efesien lagi dan kecil kemungkinannya tidak dapat diterapkan oleh bank syariah. Untuk mengatasi hal di atas maka perlu dilakukan inovasi baru dalam kontrak pembiayaan mudharabah, di mana awalnya hanya melibatkan antara dua pihak secara langsung, menjadi mudharabah yang melibatkan pihak ketiga atau yang dikenal dengan istilah mudharabah dua tingkat atau pembiayaan mudharabah pararel, yaitu melalui perantara bank syariah sebagai lembaga intermediary sehingga terjadi evolusi dari konsep direct financing menjadi indirect financing.

Adapun argumentasi hukum yang dapat disampaikan terkait dengan pembebanan jaminan dalam kontrak pembiayaan mudharabah perspektif UU No. 21 Tahun 2008 Tentang perbankan Syariah merujuk kepada prinsip kehati-hatian dan prinsip risiko. Prinsip yang sangat penting dalam rangka menjaga dan mempertahankan kepercayaan masyarakat terhadap bank syariah yaitu prinsip kehati-hatian (prudential principle). Prinsip ini dituangkan dalam pasal 35 ayat (1) UU No. 21 Tahun 2008 Tentang Perbankan Syariah. Berkaitan dengan pasal 23 ayat (1) dan (2) undang-undang perbankan syariah tentang prinsip risiko, mempertegas kewajiban bank syariah dan UUS untuk menerapkan prinsip risiko dalam melakukan

\footnotetext{
${ }^{68}$ Ktut Silvanita, Bank dan Lembaga Keuangan Lain, Cetakan Pertama, (Jakarta: Erlangga, 2009), hlm. 29.

${ }^{69}$ Krisna Wijaya, Reformasi Perbankan Nasional, Catatan Kolom demi Kolom, Cetakan Pertama, (Jakarta: Harian Kpmpas, 2000), hlm. 48.
} 
kegiatan usaha bank syariah. Prinsip risiko yang dimaksud bahwa penyaluran dana pembiayaan berdasarkan prinsip syariah oleh bank syariah dan UUS mengandung risiko kegagalan atau kemacetan dalam pelunasannya sehingga dapat berpengaruh terhadap kesehatan bank syariah dan UUS.

\section{Saran}

Melihat perkembangan pembiayaan mudharabah pada bank syariah di Indonesia, diperlukan konsep pengaturan dan tata cara pembebanan jaminan dalam kontrak pembiayaan mudharabah yang sesuai dengan prinsip syariah yang mengakomodir shahibul maal sebagai pemilik modal dalam hal ini bank syariah dan pelaku usaha, sehingga terpenuhi kepentingan pihakpihak yang melakukan kerjasama dalam kontrak pembiayaan mudharabah dan tidak ada pihak yang dirugikan. Mengingat undang-undang perbankan Syariah secara khusus telah diatur pengaturannya dalam Undang-undang No. 21 Tahun 2008, seharusnya ada pengaturan tentang jaminan syariah yang memenuhi prinsip-prinsip syariah, khususnya pengaturan jaminan dalam kontrak pembiayaan mudharabah.

\section{DAFTAR PUSTAKA}

Al-Omar, Fuad al-Omar. Haq, Muhammad Abd. Islamic Banking: Theory, Practice and Challenges. Karachi: Oxford University Press, 1996.

Al-Jaziri, Abdurrahman. al-Figh 'Ala Madzahib alArba'ah. Beirut: Dar al-Qalam.

Ali, Manzoor. Islamic Banking and Finance in Theory and Practice. Jeddah: IRTI-IDB, 1412 H/1992.

Arianto, Dwi Agung Nugroho. Peran al-Mudarabah Sebagai Salah Satu Produk Perbankan Syariah dalam Mengentaskan Kemiskinan di Indonesia, Jurnal ekonomi dan Pendidikan. 2011.

Anshori, Abdul Ghofur Anshori. Pengantar Ekonomi Syariah: Konsep Dasar, Paradigma, Pengembangan Ekonomi Syariah. Jakarta: Raja Grafindo Persada, 2017.

Ali, Zainuddin. Hukum Ekonomi Syariah. Jakarta: Sinar Grafika, 2008.

Burhanuddin. Hukum bisnis syariah.Yogyakarta: UII Press, 2011

Chapra, Umer. Prohibition of Interest: Does It Make sense?. Durban: IDM Publication, 2001.

Djamil, Fathurrahman, Penerapan Hukum Perjanjian Dalam Transaksi di Lembaga Keuangan Syariah Jakarta: Sinar Grafika. 2012.
Farah, Abdel Fattah M. An In troduction to Islamic Banking and Finance. International Islamic University: Al-KHaleej, 2009.

Hakim, Cecep Maskanul. Belajar Mudah Ekonomi Islam: Catatan Kritis Tterhadap Dinamika Perkembangan Perbankan Syariah di Indonesia. Tangerang: Shuhuf Media Insani. 2011

Harahap, Burhanuddin Harahap. Kedudukan, Fungsi dan Problematika Jaminan dalam Perjanjian Pembiayaan Mudharabah pada Perbankan syariah, Jurnal Yustisia, 2006

Hadi, A. Chairul Hadi. Problematika Pembiayaan Mudharabah di Perbankan Syariah Indonesia, Jurnal Al-iqtishad, Jurnal Ilmu ekonomi Syariah. Jakarta: Fakultas Syariah dan Hukum Universitas Islam Negeri Jakarta, 2011.

Iqbal, Zamir. Mirakhor, Abbas. An Introduction to Islamic Finance: Theori and Practice. Sinagpura:John Wileyand Sons, 2011.

Is, Muhammad Sadi. Konsep Hukum Perbankan Syariah, Pola Relasi Sebagai Institusi Intermediasi dan Agen Investasi. Malang: Setara Press, 2015.

Kazarian, Elias G. Islamic Versus Traditional Banking: Financial Innovation in Egypt. Boulder: Westview Press, 1993.

Khan, Muhammad Fahmi. Economics Series: Essays in Islamic Economic, United Kongdom: The Islamic Foundation, 1995.

Lubis, Suhrawardi K. Hukum Ekonomi Islam. Jakarta: Sinar Grafika.2000.

Muhammad Imran Ashraf, Meezan Banks Guide to Islamic Banking. Pakistan: Darul Ishaat Urdu Bazar. 2002

Muhammad, Audit dan Pengawasan Syariah Pada Bank Syariah: Catatan Pengalaman Disertai Dengan Contoh Laporan Audit dan Pengawasan. Yogyakarta: UII Press. 2003.

Muhammad. Paradigma, Metodologi dan Aplikasi Ekonomi Syariah. Yogyakarta: Graha Ilmu, 2008.

Mujahidin, Akhmad. Hukum Perbankan Syariah. Jakarta: Raja Grafindo Persada, 2016

Niazi, Liaquat Ali Khan. Islamic Law Of Contract. Lahore: Research Cell Dyal Sing Tust Library, 1990.

Usman Manzoor, Nayyer. Islamic Economic a Welfare Approach. New Delhi: Adam Publishers and Distributor, 2006.

Rivai, Veithzal dkk. Principle Of Islamic Finance (dasa-dasar keuangan Islam). Saatnya Hijrah ke Sistem Keuangan Islam yang Telah Teruji Kemampuannya. Yogyakarta: Fakultas Ekonomi dan Bisnis Universitas Gajah Mada, 2012. 
Rahman, Afzalur. Ekonomic Doctrines Of Islam. Yogyakarta: Dana Bhakti Wakaf, 1996.

Rahman, Hasanuddin. Naja, Daeng . Hukum Kredit dan Bank Garansi: The Bankers Hand Book. Bandung: Citra Adytia Bakti, 2005.

Rukmana, Amir Machmud. Bank Syariah: Teori, Kebijakan, dan Studi Empiris di Indonesia. Jakarta: Erlangga. 2010.

Sjahdeini, Sutan Remy Sjahdeini. Perbankan Syariah: Produk-Produk dan Aspek-Aspek Hukumnya. Jakarta: Kencana Prenadamedia Group, 2014.

Siddiqi, Muhammad Nejatullah. Partnership And Profit Sharing in Islamic Law. Leicester: The Islamic Foundation, 1985.

Suyatno, Thomas. H.A. Chalik, Made Sukada, C. Tinon Yuniati, Dasar-Dasar Perkreditan. Jakarta: Gramedia Pustaka Utaman Kerja Sama Sekolah Tinggi Ilmu Ekonomi Perbanas, 2007.

Suhendi, Hendi. Fiqh Muamalah: Membahas Ekonomi Islam Kedudukan Harta, Hak Milik, Jual Beli, Bunga Bank dan Riba, Musyarakah, Ijarah, Mudayanah, Koperasi, Asuransi, etika Bisnis dan lain-lian. Jakarta: Raja Grafindo Persada. 2008.

Tantri,Tamrin Abdullah, Francis. Bank dan Lembaga Keuangan. Jakarta: Raja Grafindo Persada, 2012
Usman, Racmadi. Aspek-Aspek Hukum Perbankan di Indonesai. Jakarta: Gramedia Pustaka Utama, 2001.

Umam, Khotibul. Legislasi Fikih Ekonomi dan Penerapannya dalam Produk Perbankan Syariah. Yogyakarta: Fakultas Ekonomi dan Bisnis Universisat Gadjah Mada, 20110

Usanti, Trisadini Prasastinah. Konsep Utang dalam Akad Pembiayaan Mudharabah pada Bank Syariah. Jurnal Adil. 2014.

Wiroso. Penghimpun Dana dan Distribusi Hasil Usaha Bank Syariah. Jakarta: Grasindo. 2011.

Z. Wangsawidjaja. Pembiayaan Bank Syariah. Jakarta: Gramed 